\title{
Do not forget the blood cultures!
}

\author{
Christian Scheer ${ }^{*} \mathbb{D}$, Matthias Gründling and Sven-Olaf Kuhn
}

(C) 2022 The Author(s)

We read the new international guideline on the management of sepsis and septic shock 2021 [1] with excitement and interest, as the regular updates represent the framework for sepsis therapy.

However, we were very surprised to find that blood cultures are no longer explicitly mentioned in the "Diagnosis of infection" section. The current recommendation, that "appropriate routine microbiologic cultures (including blood) should be obtained", meanwhile seems like a footnote. Is it wise not to explicitly recommend "taking blood cultures, if possible before administering any antibiotics"? We believe that in particular, many young doctors rely on clear recommendations. However, if you look for "blood cultures", you get no result in the current guidelines.

In the 2017 guideline [2], it was pointed out that "obtaining cultures before antibiotic administration significantly increases the yield of cultures and makes the identification of a pathogen more likely". In fact, there was little evidence to support this recommendation in 2017. However, in 2021, there is evidence that underlines the influence of antibiotic administration on blood culture positivity in septic patients [3-6]. These studies show that taking blood cultures after the start of antibiotic therapy can lead to a reduction in the detection of pathogens by up to $50 \%$.

It is well known that the compliance for obtaining blood cultures before antibiotics is often low [7]. It cannot be emphasized strongly enough that obtaining blood cultures is currently still a core element of sepsis diagnosis. To give away this diagnostic possibility would be foolish.

Knowledge of the pathogen is essential for bespoke anti-infective therapy, strategies for de-escalation and reduction of unjustified anti-infective therapies.

*Correspondence: Christian.Scheer@med.uni-greifswald.de Department of Anaesthesia and Intensive Care Medicine, University Medicine Greifswald, Greifswald, Germany
These strategies can be implemented in a more informed way based on blood cultures before antimicrobials, as they have a significantly higher sensitivity [3-6]. The practical remark 2017 about the number of blood cultures was deleted too. This decision also may have been made on the basis of lack of evidence, but in this way, the importance of blood cultures disappears and is only clear if previous recommendations are known.

From our point of view, the importance of obtaining blood cultures in the right way and with an adequate number of sets is an elementary and crucial part of sepsis therapy. A single set is certainly not sufficient with regard to detection of contamination or especially at the onset of sepsis. For example, in case of staphylococcal bacteremia, de-escalation based on a single negative blood culture obtained during antimicrobial treatment would be detrimental. We consider such practical advice to be very valuable. The start of antimicrobial therapy should be very well considered and this aspect is finely worked out in the 2021 sepsis guidelines. However, it is precisely with this approach that this time should be used to obtain blood cultures before antimicrobials with appropriate accuracy and appropriate number in all patients suspicious for sepsis.

Funding

Open Access funding enabled and organized by Projekt DEAL.

\section{Declarations}

Conflicts of interest

On behalf of all the authors, the corresponding author states that there is no conflict of interest.

\section{Open Access}

This article is licensed under a Creative Commons Attribution-NonCommercial 4.0 International License, which permits any non-commercial use, sharing, adaptation, distribution and reproduction in any medium or format, as long as you give appropriate credit to the original author(s) and the source, provide a link to the Creative Commons licence, and indicate if changes were made. The images or other third party material in this article are included in the article's Creative Commons licence, unless indicated otherwise in a credit line to the

\section{实


material. If material is not included in the article's Creative Commons licence and your intended use is not permitted by statutory regulation or exceeds the permitted use, you will need to obtain permission directly from the copyright holder. To view a copy of this licence, visit http://creativecommons.org/licen ses/by-nc/4.0/

\section{Publisher's Note}

Springer Nature remains neutral with regard to jurisdictional claims in published maps and institutional affiliations.

\section{Accepted: 24 December 2021}

Published: 17 January 2022

\section{References}

1. Evans LE, Rhodes A, Alhazzani W et al (2021) Surviving sepsis campaign: international guidelines for management of sepsis and septic shock 2021. Intensive Care Med 47:1181-1247

2. Rhodes A, Evans LE, Alhazzani W et al (2017) Surviving sepsis campaign: international guidelines for management of sepsis and septic shock: 2016. Intensive Care Med 43(3):304-377
3. Scheer CS, Fuchs C, Gründling M et al (2019) Impact of antibiotic administration on blood culture positivity at the beginning of sepsis: a prospective clinical cohort study. Clin Microbiol Infect 25(3):326-331

4. Rand KH, Beal SG, Rivera K et al (2019) Hourly effect of pretreatment with IV antibiotics on blood culture positivity rate in emergency department patients. Open Forum Infect Dis 6(5):179

5. Cheng MP, Stenstrom R, Paquette K et al (2019) Blood culture results before and after antimicrobial administration in patients with severe manifestations of sepsis: a diagnostic study. Ann Intern Med 171(8):547-554

6. Cascone VJ, Cohen RS, Dodson NP et al (2019) Implications of culture collection after the first antimicrobial dose in septic emergency department patients. Am J Emerg Med 37(5):947-951

7. Rhodes A, Phillips G, Beale R et al (2015) The surviving sepsis campaign bundles and outcome: results from the international multicentre prevalence study on sepsis (the IMPreSS study). Intensive Care Med 41(9):1620-1628 